\title{
Thinking Gender Differently: New Approaches to Identity Difference in the Central European Neolithic
}

\author{
Penny Bickle
}

\begin{abstract}
Gender in the European Neolithic has seen little debate, despite major scholarly interest in identity and social relationships. This article considers how gender operated in the Linearbandkeramik (LBK, c. 5500-5000 cal. BC), the first farming culture of central Europe. A new theoretical approach is developed from the philosophy of Deleuze and Guattari, and the feminist philosopher Braidotti, proposing that how difference and variation are conceived is an important element in how identity is experienced and performed. The concept of 'difference-within-itself' is introduced and applied to an assemblage of c. 2350 burials from the LBK via correspondence analysis. The results of this analysis are combined with variation in daily activities and health between malesexed bodies and female-sexed bodies to argue that differences between males and females shaped lifeways in the LBK, providing different and varied ways of participating in social life. It is concluded that there was diversity and fluidity in female identities, while male identities had more limited possibilities and were subject to further social constraints. The implications of these gendered differences for models of LBK social organization are then considered.
\end{abstract}

\section{Introduction}

Asking why 'there is so little gender archaeology for the European Neolithic', Robb and Harris $(2017,128)$ issued a call to arms for archaeologists to rethink gender in this period. They conclude that gender was not the expected binary form, found, for example, in the Bronze Age from the third millennium BC (Robb \& Harris 2017). Rather than operating as a cultural elaboration of biological sex which permeated all of social life, they argued that Neolithic gender was contextual to particular objects and practices (Robb \& Harris 2017, 141, table 1). The early Neolithic culture of the Linearbandkeramik (LBK, c. 5500-5000 cal. BC: Bickle \& Whittle 2013; Gronenborn 1999; Modderman 1988; Fig. 1) was considered an exception, particularly its burial evidence, which appeared to show more distinct binary gender patterning than elsewhere in the European Neolithic (Robb \& Harris 2017, 138, 140). Separate to the issues identified by Robb and Harris (2017), there also continues to be a tendency to treat gender as a niche, or special interest, area of study. This is problematic because many of the models for prehistoric social organization, which form the context in which issues of culture change are examined, are underpinned by an assumption of binary gender, which is itself open to interrogation. For example, recent aDNA and isotope studies (e.g. Bentley et al. 2012; Brandt et al. 2013) have confirmed earlier suggestions of patrilocal and patrilineal practices for the LBK (Eisenhauer 2003) but the implications of patrilocality for LBK identity (and vice versa) have yet to be fully addressed. Inspired by Robb and Harris (2017), this paper examines the evidence from the funerary record and bioarchaeological analysis of diet, mobility and health, asking what LBK gender was like; was it rooted in sex differences?

A significant challenge has been made to identity conceived of as a fixed means of categorizing,

Cambridge Archaeological Journal 30:2, 201-218 @ McDonald Institute for Archaeological Research 2019. This is an Open Access article, distributed under the terms of the Creative Commons Attribution licence (http://creativecommons.org/licenses/by/4.0/), which permits unrestricted re-use, distribution, and reproduction in any medium, provided the original work is properly cited.

doi:10.1017/S0959774319000453 Received 31 Jan 2019; Accepted 13 Jul 2019; Revised 12 Jul 2019 


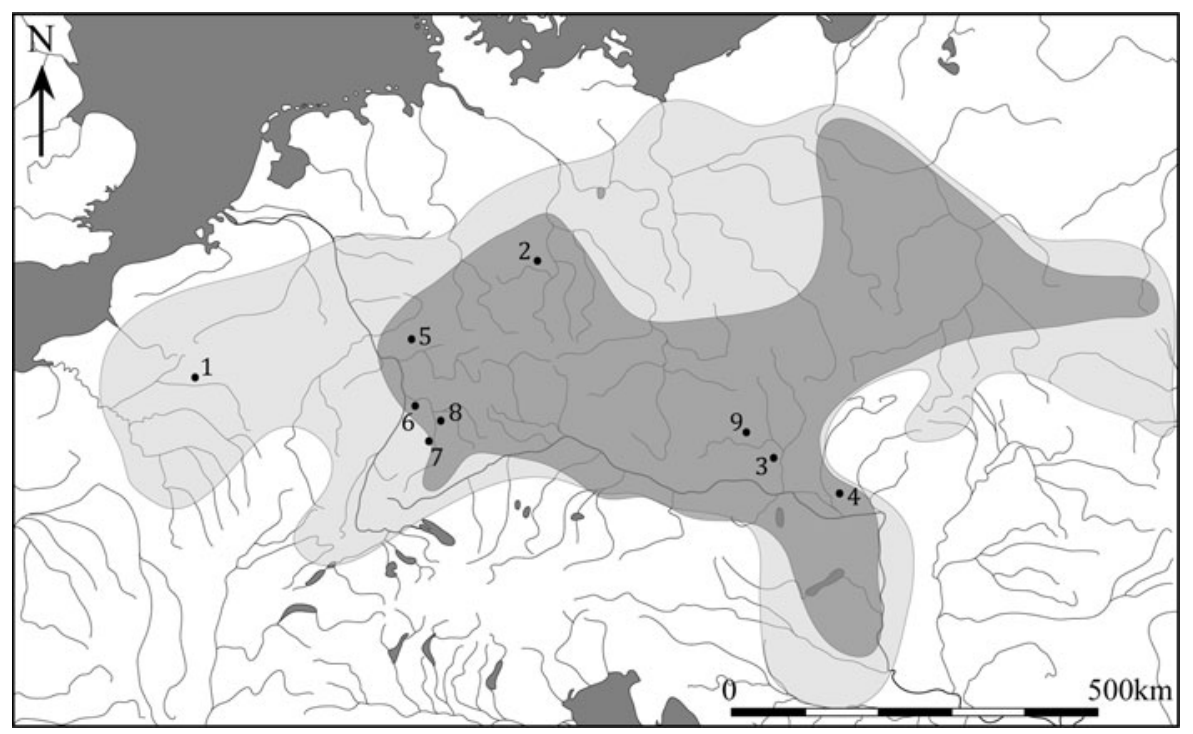

Figure 1. Map of the LBK, with sites mentioned in text. The darker shading indicates phase one (c. 5500-5300 cal. BC), and the lighter shading, phase two (c. 5300-5000 cal. BC). (1) Cuiry-lès-Chaudardes; (2) Karsdorf; (3) Kleinhadersdorf; (4) Nitra; (5) Schöneck-Kilianstädten; (6) Schwetzingen; (7) Stuttgart-Mühlhausen; (8) Talheim; (9) Vedrovice. (Base map after Jeunesse 1997, 10, fig. 1.)

and thereby defining, a person (Joyce 2000; 2008; Meskell \& Joyce 2003; Milledge Nelson 2006). Rather, it is figured as the myriad ways of participating in and creating social life, a definition developed in part from feminist philosophy (e.g. Butler 1990; 1993; Grosz 1994; 2011). In the specific case of gender, this means recognizing that the division between sex as a biologically fixed category and gender as its cultural elaboration developed from the particular historical circumstances of the Enlightenment (Meskell 1996; Robb \& Harris 2013; 2017; Thomas 2004). Therefore, rather than judging the archaeological evidence against a list of what are assumed a priori to be facets of identity, alternative ways to capture the creation and performance of identity are required. Instead archaeology has turned to conceptions of embodiment and personhood, leaving gender and biological sex in an uneasy relationship with our interpretations of identity, to the extent that they have sometimes been overlooked (Robb \& Harris 2017). Most importantly, however, I contend here that it has meant that that difference in identity has been under theorized.

If gender is considered a fixed category, rooted in the body, then difference can clearly be found in biological sex. However, if identity is characterized as contextual, arising in daily practice, and fluid, differences between identities become more challenging to define (Moore 1994a, 37). An alternative approach to identity difference is proposed here based on the philosophy of Deleuze (2009; Deleuze \& Guattari $2013 a, b)$. I also draw on feminist reactions to Deleuze's concept of difference (e.g. Braidotti 2011; 2013; Moore 1993; Stark 2013) and archaeological borrowings from these scholars (Crellin 2017; Fowler 2013; Harris 2017; 2018): what is now loosely called the 'New Materialist' school (Harris \& Cipolla 2017). Deleuze's philosophy sought to reject Freudian definitions of difference (called here Freudian for the sake of clarity, following Braidotti 2011 and Stark 2013, who use the term 'psychoanalysis'). Freud's account of sexed difference characterizes many of the post-Enlightenment approaches to difference: that in order for two things to be different they must lack what the other possess and are thus a priori defined by each other (Butler 1993; Moore 1993; 1994a). For example, in the classic Freudian approach to sexed identity, the female lacks what makes the male 'man', and thus women participate in their social relationships by virtue of not being male (Butler 1993; Grosz 1994). In contrast, the Deleuzian approach to difference is defined as 'difference-within-itself' (Deleuze 2009; Deleuze \& Guattari 2013a), that is, difference as a productive and energized space, out of which things, people, identity are created (or 'become', in the terms of Deleuze and Guattari). While the former approach encourages attention to normative definitions (whereby things are categorized by the presence of something or by lacking it), a Deleuzian approach 
pays greater attention to the diversity, or difference defined-within-itself; the range of possibilities rather than the average.

\section{Theorizing difference positively: towards an analytical framework}

There are two key concepts, assemblages and becoming, which have been the focus for most archaeological interpretations of Deleuze (Crellin 2017; Harris 2017). Although both terms can only briefly be considered here, it is useful to outline how they reframe approaches to archaeological evidence. Assemblages are what the world consists of, the myriad of interacting and animated elements (material, linguistic, symbols, representations) that form complexes, encompassing everything from molecules to whole-world systems and, importantly, expressions of those complexes (Crellin 2017; Delanda 2006; Deleuze 2009; Harris 2017; 2018). They are thus multiscalar and can be both managed or managing (or in Deleuzian terms, territorialized or deterritorialized: Deleuze \& Guattarri 2013a). Harris $(2018,8)$ explains assemblages through the concept of a house: the house is an assemblage of materials (such as the bricks, mortar and furniture), linguistic concepts (bedroom, kitchen, domesticity), symbols (privacy, social class, wealth) and representative (ownership, capitalism). The assemblage of the 'house' is constantly produced through the interaction of these difference elements, in other words, becoming (see below), and subject to change in multiscalar ways, from knocking down walls as open-plan living becomes desirable to developing notions of overcrowding, as political situations allow slum landlords to thrive.

In the example above, thinking of the house as an assemblage asks us to attend to how concepts of ownership of space, privacy and divisions between domestic life and work dovetail with material properties and their variation in time and space. It also shapes the questions to ask: no longer is it useful to ask what is a house? or what does a house mean? Or, even, what does a house do? It forces us to ask how does the house participate in the world or, importantly, how does a house become an outcome of actions in the world? We can extend this to gender. The question is no longer what is gender? But rather how does gender allow 'people' to participate in the world as active? How is gender produced, or an outcome of actions in the world? Assemblages are thus gaining traction as productive approaches to archaeological evidence, particularly around challenging categories of evidence previously thought of as exclusive. This has important implications for detailing how change may have occurred from within assemblages rather than being enforced from outside (e.g. Crellin 2017).

The concept of assemblages as constantly becoming has mostly been used in archaeology to encourage a flattening of existing interpretative hierarchies, in which materials, objects and animals participate as much as humans in the ongoing creation of particular historical phenomena (e.g. Crellin 2017; Fowler 2013; Harris 2017; 2018). Deleuze and Guattari $(2013 a, b)$ figure becoming as more a complex process than a constant state of emergence. For Deleuze and Guattari (2013a), becoming is the means by which difference is produced in new, positive ways; their aim was to find ways of reconfiguring identity to escape political hierarchies. Of particular importance to the concept of 'becoming' is the rhizome, a term borrowed from biology. A rhizome is a plant root which grows from nodes sent outward horizontally, from which new shoots can grow (Deleuze \& Guattari 2013a). They contrast rhizomic becoming to other philosophical approaches to knowledge, which they cast as linear and hierarchical (Deleuze \& Guattari 2013b). Knowledge as linear, with difference defined-by-lack (difference defined in the Freudian sense outlined above), Deleuze and Guattari (2013b) argue leads to hierarchical arrangements in assemblages because one element of the assemblage takes primacy in the definition of the others. For example, in Freudian thought, where the female desire is defined by what females lack physically, this supports the primacy of male in the definition of gender (man can be neutral, but never female), hence propping up Enlightenment binaries (Braidotti 2011; Butler 1993; Moore 1993; 1994a; Stark 2016).

To move from difference defined-by-lack and towards difference defined-within-itself, Deleuze and Guattari (2013b) argue that one must move through multiple specific becomings, such as becoming-women, becoming-girl, becoming-animal and becoming-molecular (see discussion in Stark 2016). Contra all sense of a concrete, substantive world being lost in endless fluid assemblages, assemblages constantly become so that particular and specific views are made possible, or crucially, re-enforced; 'the condition in which an eventful subject apprehends a variation ... or [that] something = $x^{\prime}$ (Deleuze 2009, 21). Therefore, to examine an assemblage without considering whose 'views' or the 'something $=\mathrm{x}^{\text {' }}$ is to miss a critical element of Deleuze's argument. For feminist philosophers inspired by Deleuzian thought, such as Rosi 
Braidotti (2011), it is the concept of occupying simultaneous multiple becomings, rather than becoming as a constant, which allows new identities to emerge which challenge the dominant mode of thought, with male as subject and female as other. Braidotti $(2011 ; 2013)$ argues that collapsing difference between men and women (or regarding them as a continuum) will not bring about an end to the impacts of sexism, but rather it is necessary radically to rethink how difference between people is conceived and understood. To disrupt the unequal hierarchy between masculinity and femininity thus involves challenging the view of the sexes as mutually constituting (Busby 1999). Of course, and as experienced, gender is fluid and highly varied, but rarely represented as such, creating a 'noticeable gap' between how we live and how we represent lived experience (Braidotti 2013). This results in sexual difference being reinforced (as 'something $=\mathrm{x}^{\prime}$ ), as the responsibility for the mismatch between experience and ideal is placed in the hands of the individual, rather than the failure of the concept of binary sexual difference to account adequately for human experience. Braidotti $(2011,4)$ uses nomadic subjects to move beyond this. She charges her nomads to move rhizome-like between multiple embodied voices that encompass the feminist movement, denying othering through action-to be more concerned with the variation within (Braidotti 2011, 161-5). Following Braidotti (2011), this can be achieved through greater attention to diversity and variation, to difference-within-itself. We can apply this to archaeology by considering the diversity within the assemblages considered of value to understanding the past.

To summarize this discussion, three important elements of Deleuzian thought have the potential to impact on how we define difference, each of which suggests a route forward to alternative archaeologies of identity:

(1) The concept of assemblages encourages us to explore how materials, objects, people, animals, architecture and so on, operated together to create particular, multiple and specific ways of participating in and of the world.

(2) Being alert to where the differences recognized as important in the past are defined-by-lack. Are Enlightenment binary hierarchies of subject/other being recreated or re-enforced through particular narratives of the past?

(3) Attempting to recognize difference definedwithin-itself by seeking diversity within multiple ways of participating in identity in the past.
For the discussion here, this means first exploring how sex and gender differences have been defined for the LBK, and the impact of those differences on interpretations of LBK social worlds. Whether concepts such as biological sex, gender and differences based on sexual reproduction might have facilitated particular participations in LBK society, and how gendered identities might have been produced, are then considered through considering diversity within assemblages first of burials, and then of bodies.

\section{Gender in the early Neolithic: the case of the LBK}

The early Neolithic LBK culture (5500-5000 cal. вс) originates in the region of modern Hungary and brings the Neolithic to central Europe, stretching from the Paris basin to Ukraine (Bickle \& Whittle 2013). This geographical scale frames the analysis presented here, though it would be a mistake to suggest that this distribution did not also include regional differences, and that more refined study may lead to regional nuances in gendered experiences. There are few explicit considerations of sexor gender-based identities in the published literature on the LBK, which, as Robb and Harris (2017) note, is common for the European Neolithic. This does not mean, however, that LBK scholars have ignored gender, or rather the categories of man and woman (e.g. Jeunesse 1997; Moddermann 1988; Nieszery 1995; Pavúk 1972; Röder 1998; van de Velde 1979a, b; Veit 1993; 1996). A review of how LBK gender has been interpreted is instructive of how difference defined-by-lack has led to the reproduction of modern binary gendered hierarchies. Sex and gender appear within two broad themes of LBK social organization. The first theme is kinship, including lineage, post-marital residential rules and status, which is mostly drawn from the burial evidence. The second is the sexual division of labour, often assumed in material culture production. Such normative characterizations of men and women have been challenged through considering the impacts of age and other forms of embodiment (Hofmann 2009, 224; 2013).

\section{LBK gender in death}

Statements about sex or gender in the LBK are mostly limited to the burial evidence, and hence connected to sexed skeletal remains. That women and children were of lower status to men is a prevalent suggestion in the literature (Häusler 1994; Jeunesse 1997; Moddermann 1988; Nieszery 1995; Pavúk 1972; Röder 1998; Veit 1996; Fig. 2). Sometimes this 
is explicitly stated (e.g. Dohrn-Ihmig 1983; Jeunesse 1997, 95-9; Röder 1998, 257), other times implied by absence and a focus on how male status operated (e.g. Moddermann 1988, 119; Pavúk 1972). Their implied lower status rests on two characteristics of the burial evidence: first, that women and children receive fewer grave goods than men, and secondly, that they are more frequently buried at settlement sites (Hofmann 2009, 224-7). Reviewing the impact of sex on the rate of furnished graves and burial locations (cemetery or settlement) from a database of $c$. 3000 LBK inhumation burials, Hedges et al. (2013, 373-4) found no statistically significant differences between men and women. Female sexed skeletons are under-represented at cemeteries, but not drastically so, though they are less likely to have grave goods. Importantly, men and women were equally likely to be buried at settlements, where burials are less likely to be furnished (50 per cent furnished graves at settlements, compared with 70 per cent at cemeteries: Hedges et al. 2013, 374). The evidence does not confirm that women and children had lower status. Rather, such notions appear to develop from selected reading of the evidence, built on assumed differences in how cemeteries and settlements, and specific grave goods, are thought to have been valued by LBK communities (Hofmann 2009).

One particular grave good, polished stone tools, stand out as the 'male' grave good by virtue of being found in male graves (e.g. Moddermann 1988, 119; polished stone tools appear in 34 per cent of all male graves and 5 per cent of female: Hedges et al. 2013, 378; Fig. 3). There is no easily identifiable 'female' grave good counterpart, though some grave goods have been proposed. One such example is grinding stones (e.g. van de Velde 1979a, b; Zvelebil \& Pettitt 2008, 202), but this is, again, cannot be established by the analysis of both settlement and cemetery burials, with grinding stones in $5 \%$ of burials, irrespective of sex (Hedges et al. 2013, 379). This patterning therefore suggests that stone tools do not operate to mark maleness as opposed to femaleness. Following on from this, we can question whether grave goods tell us much about gender construction, and whether sex had a role in conferring higher or lower status on particular individuals in the LBK at all (a point returned to below). In summary, the supposed status of LBK males is largely developed from what others lack.

\section{LBK gender in life}

The characterization of LBK gender from the burial evidence is often repeated in the consideration of

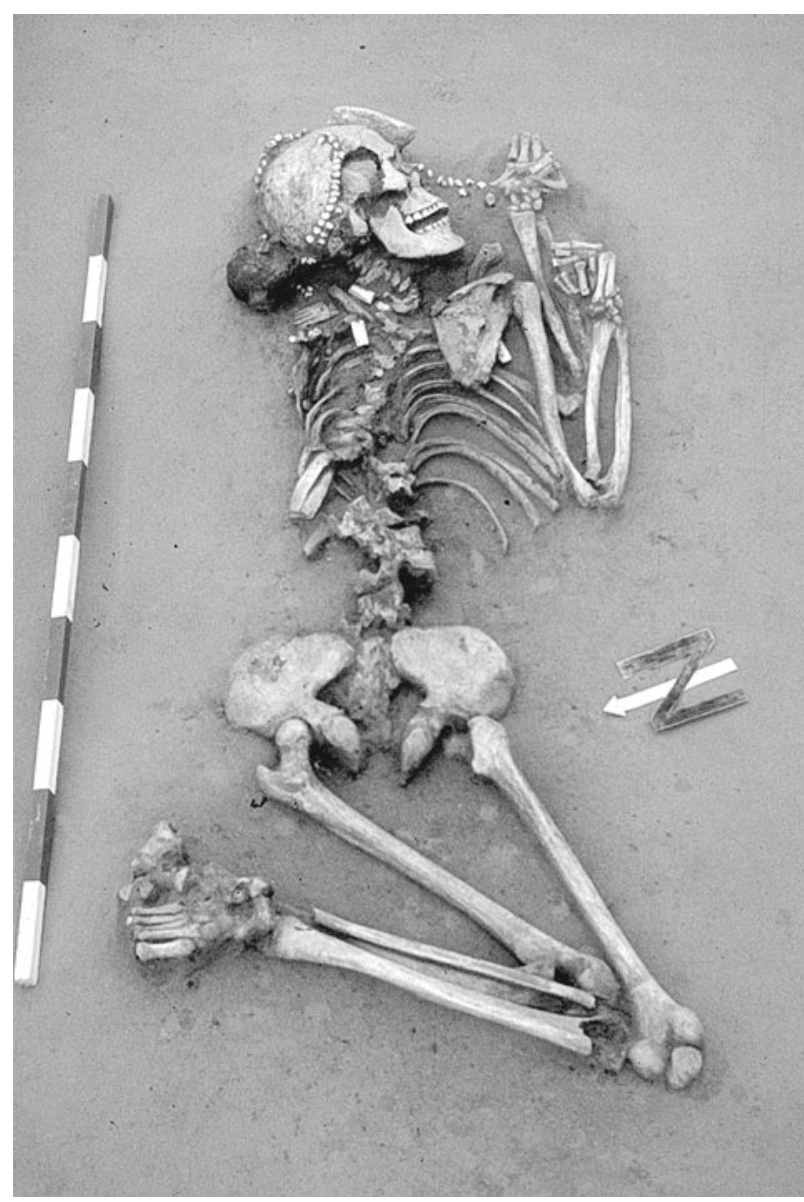

Figure 2. The 'standard' burial rite of the $L B K$, left-crouched, oriented east-west and with a set of grave goods. Burial 60, from Aiterhofen-Ödmühle (Bavaria, Germany; adult female, 40-50 years). (Photograph: Bayer. Reproduced with the kind permission of the Landesamt für Denkmalpflege, Regensburg.)

daily activities and tasks. Women are the potters, while men are the knappers (e.g. Strien 2000). This classification is derived in part from how these two classes of material culture operate. Smaller decorative pot motifs (called 'secondary' motifs) are thought to represent the individual potter, with some in use for up to 250 years (Krahn 2003). Women are thought to have brought these secondary motifs from the place where they learnt to make pottery to the settlement of their 'husbands' (Claßen 2009, 101). Lithic traditions, in contrast, appear to stay more stable, following similar networks across the duration of the LBK (Claßen 2009; Strien 2000). For Sommer (2001, 260), the forms of variation accepted in ceramics and lithics were part of an LBK ideology of cohesion, carefully monitored in the material culture which expressed it. This 


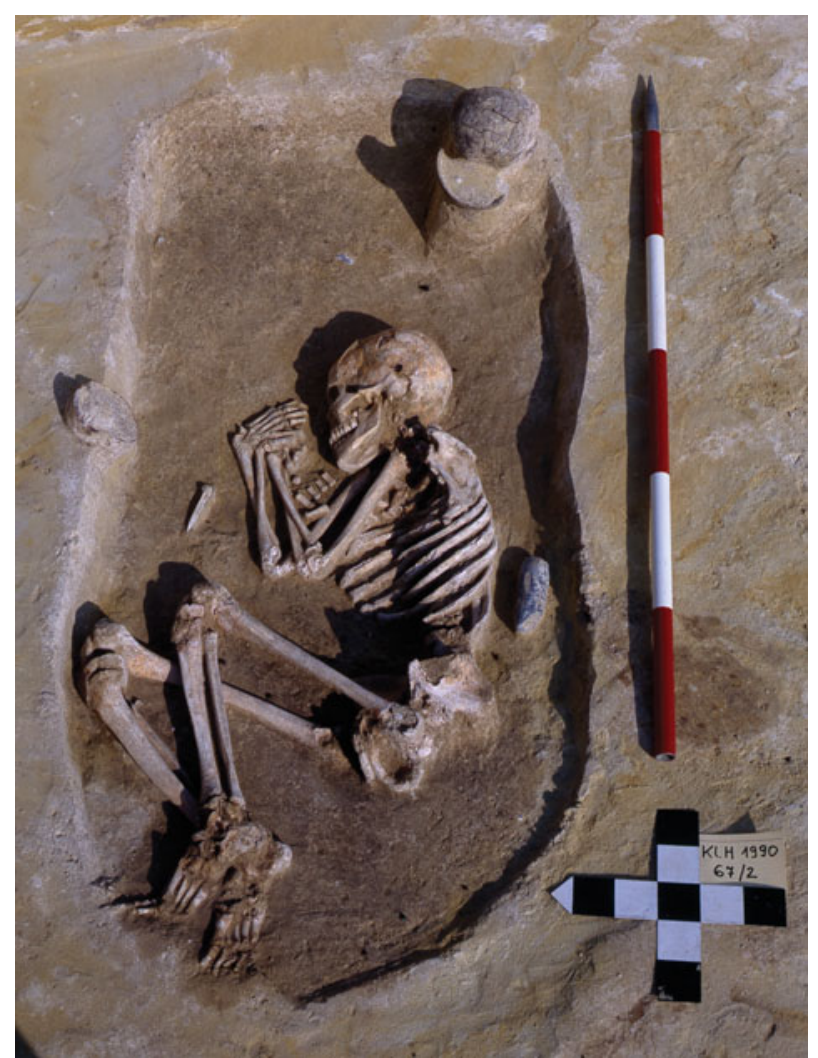

Figure 3. Burial 67/2 from Kleinhadersdorf (Austria; young adult male). Note the polished stone adze placed behind the spine of this right-crouched individual. (Photograph: J.-W. Neugebauer, BDA.)

ideology, Sommer argues, had a gender basis, which is worth quoting here in full:

Traditionally, ceramics are seen as a female product and lithics as a male product. This would mean that the cultural unity was guaranteed by the products of the women, while the products of men could safely be ignored, as they bore much less of a cultural message. A patrilocal marriage system would lead to a constant inter-settlement and perhaps interregional exchange of both personnel and information-and might place the young potteress under the close supervision of a tradition-abiding mother-in-law. (Sommer 2001, 260)

Given the diversity of pot decorations, locally and regionally, we could counter-argue that pottery is subject to more and faster change, and cultural variability, than lithics.

Prioritizing pottery and lithics as representations in gender relations creates two separate spheres of activity, one for each item of material culture. This contrasts with how pots and lithics are usually found, mixed together and fragmented, often dispersed across a settlement. Specific task locales are sometimes identifiable, such as lithic-processing areas (Hachem 2000, 308; Lanchon et al. 1997, 328; Last 1998; Wolfram 2013), but for the most part distinct activity areas do not appear at settlements. The division between pot making and lithic production also betrays a particular view of these activities, again one in which an idealized norm is prioritized. The focus is thus on the final form of the object, and often just one feature of it (pots = decoration, lithics = raw material source), rather than the assemblage of materials, people, landscapes and time that went into production, for example, in the case of a pot: the sourcing of clay and temper, the mixing, decorating, forming, and firing, the repeated usage and possible repair, before eventual deposition (Gomart 2014). The point stressed here is that assuming $a$ priori men and women as valid categories of analysis is not neutral and will lead to other binaries in our interpretations. This is because gender is an assemblage: it carries with it not just 'maleness' and 'femaleness', but also its structuring role in creating binary oppositions and hierarchies, which spread rhizome-like through the data.

\section{Alternative views of LBK identity}

Using 'men', 'women' and 'children' as normative categories in the LBK has been successfully challenged (e.g. Hofmann 2009; 2013; Hofmann \& Whittle 2008; Jones 2005; Whittle 2012). One good example of this is Hofmann (2009; see also Hofmann \& Whittle 2008), who explores how grave good assemblages vary with the age of the deceased, with more overlap between men and women as they aged. This elaboration of age in the funerary sphere suggests identity was not stable across the life course, and may indicate that ageing was an important process for shaping identity in the LBK (Bickle \& Fibiger 2014). Household membership is also considered as a distinct identity category (Hofmann 2013; Jones 2005; Whittle 2012). Exploring the diversity of longhouses in form, temporality and relationships to other houses does much to challenge the house, and by extension, the household as an exclusive category of social organization (Whittle 2012, 195-6). Hofmann (2013) points to recurrent and regular concern with the decay and dissolution of both the body and the house. For the body, this took place through the funerary sphere, whether through cremation, disarticulation or revisiting/viewing the body, evidenced through the deliberate moving of bones out of anatomical connection (Boës 2000; Hofmann 2013; Thévenet 2009): for the house, through engagement with repair, open and flexible internal spaces 
and dissolution at the end of its life (Hofmann 2013, 161-2). This fits Whittle and Bickle's (2013, 390-91) suggestion of a strong concern with descent and lineage in the LBK, evidenced across multiple categories of evidence, mostly patrilineal, but also flexible. Rather than distinct categories persisting across all spheres of life, Hofmann $(2013,166)$ argues that both possession and flow were present, with lineage maintained through both 'connection' and 'categorization'.

\section{Multivariate analysis of LBK grave goods}

To understand how such as 'connections' and 'categories' (Hofmann 2013) may have facilitated particular ways of participating in LBK life, I turn to explore the assemblages of burials. However, it is first necessary to consider the interpretive bias provided by the sexing of skeletons. Methods used in the 1960s and '70s produced a systematic bias in which skeletons were 12 per cent more likely to be sexed as male, particularly in older age categories (Weiss 1972). Male and female skeletal morphology is a continuum, rather than two absolute categories (Chamberlain 2006). Individuals who cannot be sexed are usually excluded from further analysis, particularly with regard to grave goods (Stratton 2016, 859). Geller $(2008,128-9)$ suggests the way forward is to attempt to 'distinguish difference in terms of variability and continuum'. For Stratton (2016, 863), this meant carrying out multivariate statistical analysis to examine connectivity between artefact types. Using correspondence analysis on the Bulgarian late Neolithic site of Durankulak, few patterns were found, with grave goods types found evenly distributed across male, female and unsexed adult graves, suggesting gender was not 'fixed' through the funerary rites (Stratton 2016, 866).

Following the methods of Stratton (2016) as a means of determining difference defined-withinitself, a simple correspondence analysis was carried out on the data collected for Bickle and Whittle (2013). Correspondence analysis uses chi-squared tests to define the relationships between variables, which are expressed graphically, with the axes describing the variation in the dataset (Baxter 1994). The analysis was confined to furnished adult burials (2342 burials: 545 females, 539 males and 1258 indeterminate adults), divided into seven categories of sex (f, $f$ ?, $f$ ??, indeterminate, $m, m$ ?, $m$ ??) and seven categories of grave good (stone tools, pottery, shell, flint, ochre/colour, bone, miscellaneous). This analysis is based on burials sexed using different osteological techniques, including older or unknown methods (Grauer 2012). Categories of grave good were decided on prevalence, with any grave good with a frequency of less than 10 per cent included in the miscellaneous category (including unworked animal bone, grinding stones and boar tusks). These categories are somewhat problematic, as they contain distinct variation within each of them; for example, bone can be found as both tools and personal ornamentation. Some animal bone objects appear in low numbers, but almost exclusively alongside male skeletons. Bone or antler pendants appear in 29 male graves, and 3 female (Haack 2008, 124-5), while, in yet lower numbers still, similar ratios are seen with wild boar tusks, fox mandibles and antler products. However, the categories chosen allow for some observations (Fig. 4). Confidently sexed male skeletons appear to have a strong association with polished stone and flint tools, whereas females are associated with pottery and shell, but more weakly. Bone and ochre were not associated with any sex. Indeterminately sexed skeletons were not associated with either group, but were more closely linked to ochre. F?? burials appeared closer to $\mathrm{m}$ and $\mathrm{m}$ ?? than did $\mathrm{m}$ ? burials. Overall, the results do suggest that biological sex was impacting on grave good assemblages to some extent, and certainly more in comparison to Durankulak (Stratton 2016).

Given that the polished stone tools appear to have such a strong impact on the results, they were then removed from the analysis with the result that the patterns outlined above broke down (Fig. 5). There are some weak associations between pots, worked bone objects and shells co-occurring in graves, but as these are the most frequently present grave goods by number it is not surprising. What the second plot does reveal, however, is that the view of 'women' and 'children' as having less status than males, on the basis of the burial evidence at least, is probably an artefact of the presence of polished stone in male graves. This analysis, in contrast, provides a compelling case for viewing polished stone tools as having more impact on the rest of the grave good assemblage than the sex of the individual in the grave, the implication being that sex was a secondary factor to other concerns when grave good assemblages were compiled. These results echo the findings of the univariate analysis in Hedges et al. (2013, 372-84). In this analysis, grave goods were analysed for how 'strongly' sexed they were based on their frequency in sexed burials (Hedges et al. 2013, 378, table 9.10). Female-sexed skeletons, for the most part, could receive a wider and less sex-determined range of 


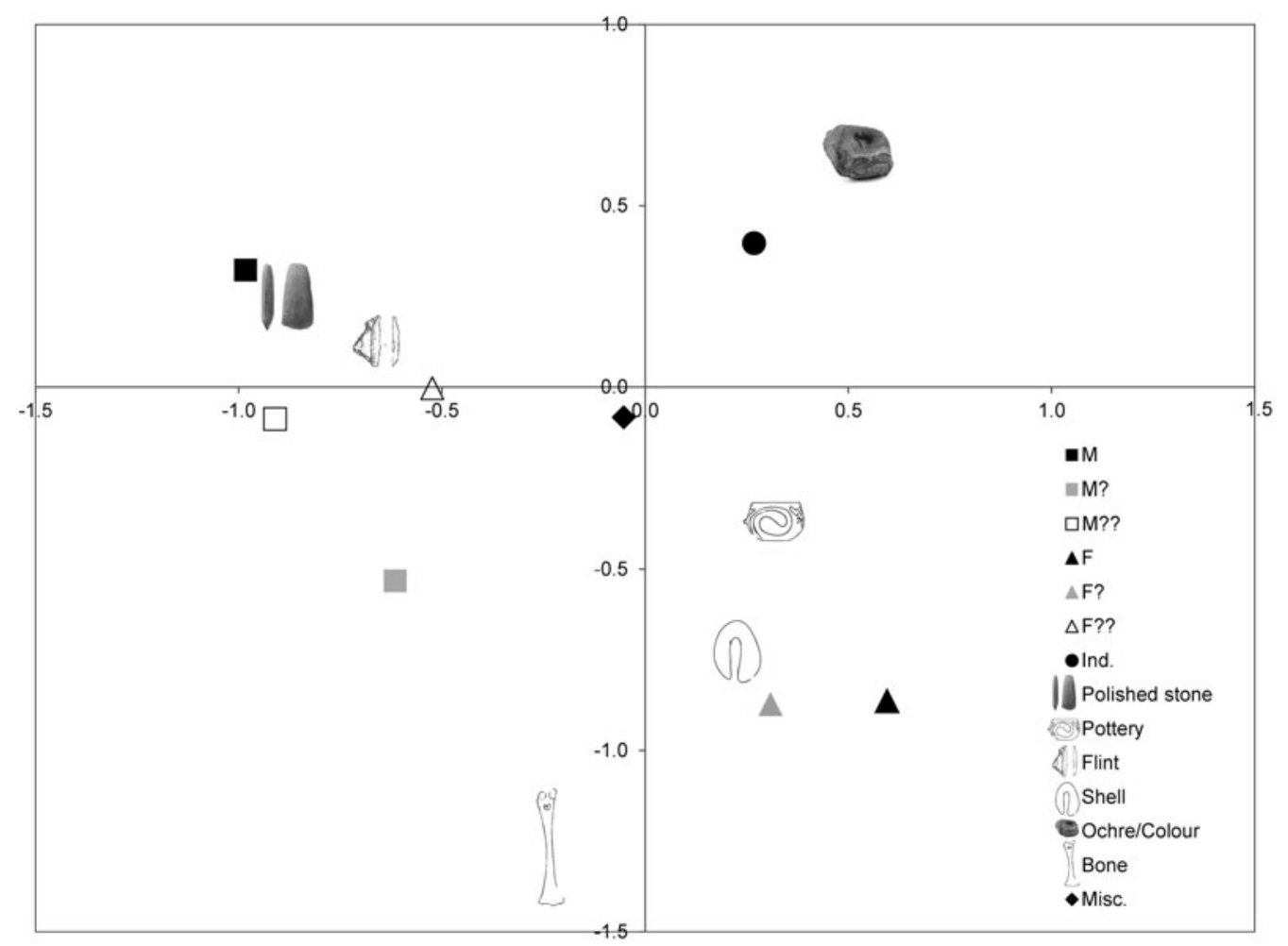

Figure 4. Biplot of the correspondence analysis results from the grave goods and sex of burials in the LBK.

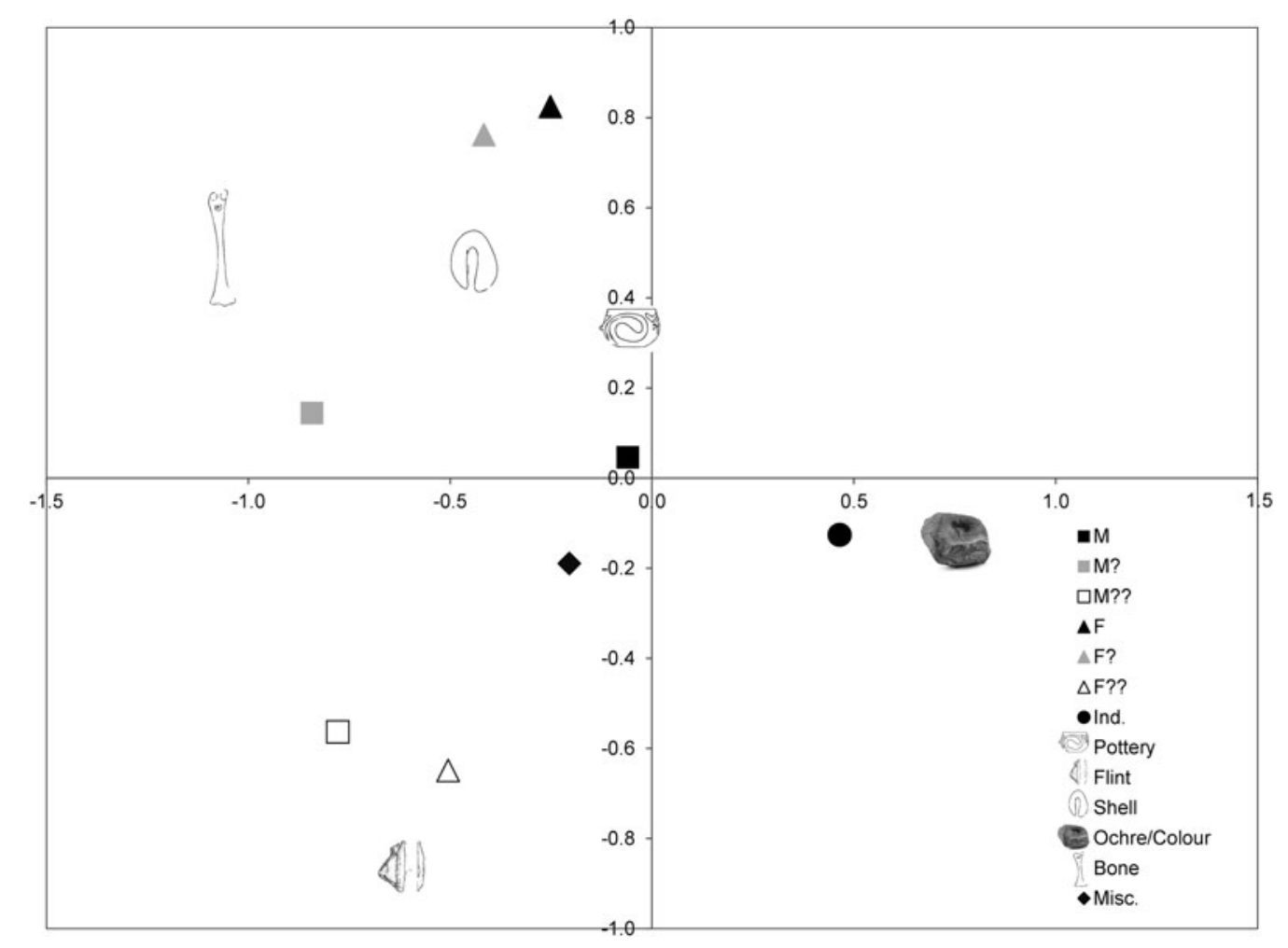

Figure 5. Biplot of the correspondence analysis results from the grave goods and sex of burials in the LBK, this time with polished stone tools excluded from the analysis. 
grave goods, while for some male-sexed skeletons the presence of a polished stone tool led to a more restricted burial rite in terms of grave good. There was no statistical difference in the orientation or body position between the sexed skeletons, or in association with stone tools (Hedges et al. 2013, 376-7). In sum, grave goods were in a minor way being influenced by the biological sex of the individual in the grave, but body position and grave orientation were not (in comparison to late Copper and Bronze Age burials: Sofaer Derevenski 1997). In the LBK, age of the deceased also correlates with increasing or decreasing frequency of grave goods (Hedges et al. 2013, 379; Hofmann 2009) and body position (Bickle \& Fibiger 2014). Rather than defining the whole set of funerary rites, sex thus appears in a small part of the funerary sphere, related to selection of a limited range of grave goods.

The polished stone tools found in graves range from heavily worked to pristine, and include flakes and fragments (Röder 1998, 252). Some of the tools were in use for up to 15 years (Ramminger 2007, 264) and were probably used for working wood (Modderman 1988, 113; Ramminger 2007). Other polished stone tools were not used and were possibly made for the grave, never intended to be put to work (Ramminger 2007). Tools were made of stone from outside the local area, sometimes having travelled significant distances (Ramminger 2007; Strien 2010). Some were placed whole, others were deliberately broken. For example, at the cemetery of Vedrovice (Czech Republic), two broken adzes were placed at the knees of an adult male (Fig. 6). Polished stone tools are also found in myriad locations in the grave, both on and off the deceased, which might also have been used to make particular statements. At the Kleinhadersdorf cemetery (Austria), polished stone tools are sometimes found placed along the back or front of the individual, and sometimes on top of the body, and sometimes on the edges of the grave cut at some distance from the body, whereas ochre is almost always found spread beneath or around the head (Neugebauer-Maresch \& Lenneis 2015; Fig. 3). In sum, this potential variation in object biographies before burial, and in the grave itself, suggests that although adzes were overwhelmingly placed in male graves, and brought with them increased likelihood of other objects being placed in the grave, they were themselves not adhering to strict rules or normative practices. Whether the personal object of the deceased, or a gift from a mourner, the adze would have carried with it these wideranging associations. Bringing these elements together, we can consider the adze assemblage.

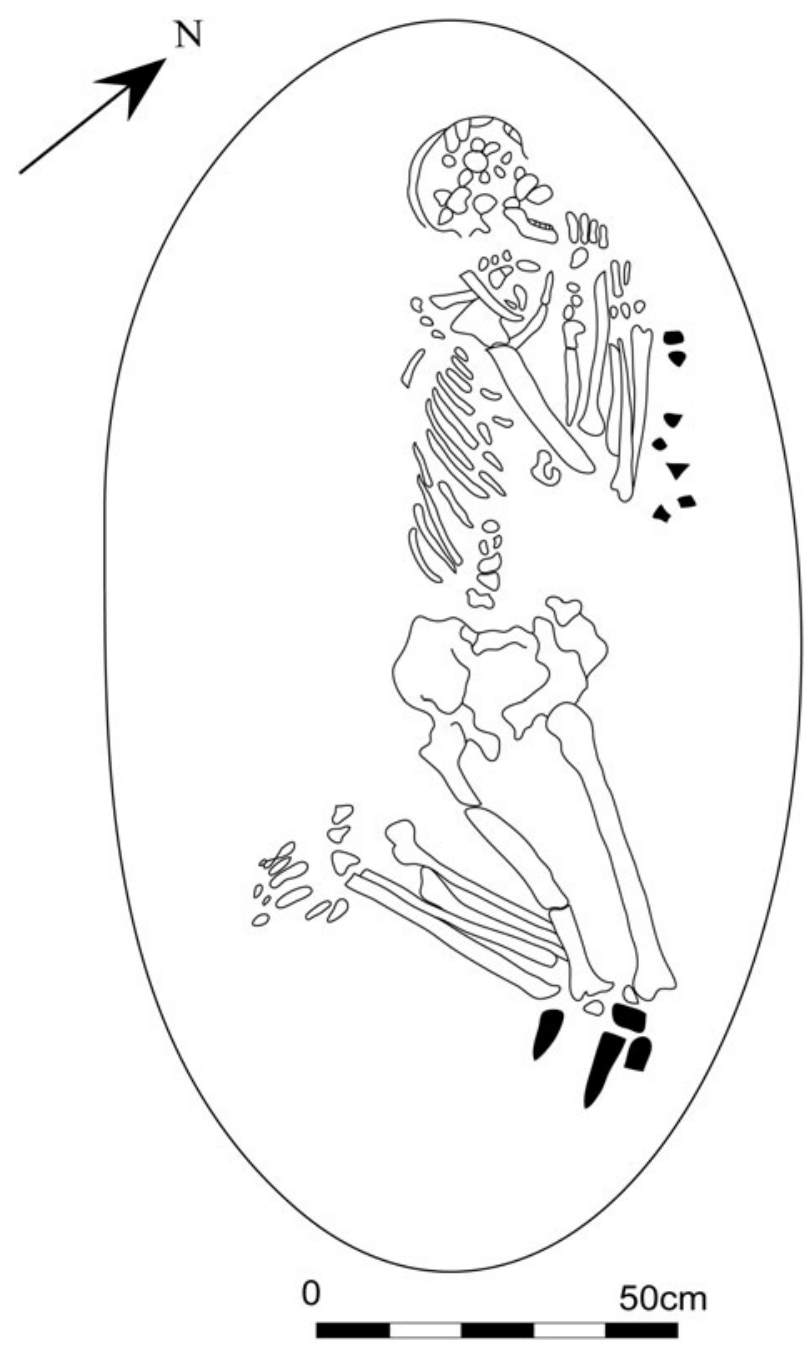

Figure 6. Burial of an adult male (Vedrovice, Czech Republic, grave 57/78). The two broken adzes located by the knees are depicted in black. (After Whittle et al. 2013, 117, fig. 4.5.)

Perhaps responsible for constructing longhouses and clearing the forest before crops were grown, they may have been involved in the reproduction of the community or household, and through their origins signalled connections beyond the immediate social sphere.

Given the patterning in grave goods outlined above, it is perhaps not surprising that the only correlation between grave goods and isotopic data was with polished stone tools; adzes were found in the graves of men with a restricted range of strontium isotope values (Bentley et al. 2012). As the strontium isotope value comes from tooth enamel, which forms in childhood, and adzes were received on death, in adulthood, this suggests a particular lifeway for 
some LBK males, possibly associated with the inheritance of land (Bentley et al. 2012). For Hedges et al. $(2013,381)$, this connection, combined with the analysis of funerary practices, suggests that 'masculine identities were presented in more closely regularized, perhaps formalized ways', with male graves the focus for concern with male lineages. On balance, the funerary sphere probably does tell us more about concern with these (for want of a better term) lineages than how and whether sex was elaborative basis for gender construction in the LBK. Burial practices hint at concern with connections and links, rather than repetition of idealized identities (Hofmann 2009). On the one hand, this leads to the variation seen across all regions and elements of burial (Hedges et al. 2013, 382): on the other hand, it leads to clustering around certain funerary practices (particular body positions, tendencies towards an east-west grave orientation, the objects selected to be placed alongside the deceased), in which identities relating to biological sex only appear if we look at the data in particular ways. For example, how might using microwear analysis on bone and stone tools to determine the activities represented in the grave, or perhaps comparing where objects were placed in the grave, change this analysis?

\section{Sexual division of labour in LBK lifeways}

If, in death, we glimpse some minor but meaningful differences suggesting the participation of biological sex in identity formation, might it also be present in other areas of evidence as well? Strong sexual division of labour is often assumed for non-industrial societies, such as early farmers, with variation considered to occur across different age groups (Macintosh et al. 2017; Moore 1994b), and the LBK is thought to be no exception. As we saw above, lithics are often strongly associated with men, pots with women. This section will consider whether particular genders or gendered experiences were produced in labour and everyday tasks. To explore this, we can turn to the available bioarchaeological data, again considering variation as a means of investigating the difference defined-within-itself. Two sources of evidence are drawn on here: isotopic data and osteological studies of pathologies and stress markers where available. Issues discussed above pertaining to how biologically sexed skeletons are used to inform the analysis are important here. For the most part, bioarchaeological studies report only on the differences between male and female skeletons, and often without recording the basis on which skeletons have been sexed and confidence in the assignment of sex. This is a challenging problem, and it is proposed here that greater attention to the variability of the data is required, that is, aiming to consider the variation within the dataset, rather than the average.

Limited studies of how repeated activities may have been recorded in LBK skeletons have been carried out, but the number is growing. Villotte and Knüsel (2013) analysed the prevalence of stress markers on the elbows of the adult population from the LBK cemetery of Stuttgart-Mühlhausen (Baden-Württemberg, Germany), and found a prevalence of right medial epicondylosis among the adult males only found in modern baseball pitchers. This leads Villotte and Knüsel $(2013,172)$ to argue that males, more than females, were engaging with repeated overhead throwing activities, which may have been related to hunting through the use of projectiles or throwing stones. While the stress marker occurs on one-third of male skeletons, it is challenging to determine the extent of this activity within the population. Post-cranial trauma was found in higher frequencies among male skeletons at five LBK settlement and cemetery sites, which was interpreted as males more likely than females to undertake activities with a higher risk of injury (Hedges et al. 2013, 371). Judd and Roberts $(1999,240)$ suggest that high rates of fracture in medieval farming populations were due to handling animals (e.g. kicks) and falls (e.g. ladders), which may explain some differences in how farming tasks were distributed across the community.

Sládek et al. (2016, 43) found that sexual dimorphism in upper limb bone bilateral asymmetry rose from the Mesolithic to the Neolithic among the populations they studied, drawn from across Europe. Crucially this was because of changes in female activity patterns, rather than male, which they relate to the repeated use of saddle querns (Sládek et al. 2016). Upper limb loading, which indicates strength and extent of limb use, indicates that LBK women were participating in very high levels of manual labour, possibly explained by spending hours a day grinding using a saddle quern, but also through activities related to growing crops, such as tilling, hoeing and so on (Macintosh et al. 2017). This data is characterized by lower variability than the lower limb loading, in which Macintosh et al. $(2017,2,6)$ found 'notably high' variation in the tibias of LBK female skeletons, encompassing almost the entire known range from living populations, including athletes. Values from male tibias were for the most part less varied, though regional trends could be identified (Macintosh et al. 2014, 
384). At the eastern-LBK Nitra (Slovakia) and Vedrovice (Czech Republic) cemeteries, the ranges in tibia midshaft variables were more restricted than they were in the western-LBK cemeteries of Schwetzingen and Stuttgart-Mühlhausen (BadenWürttemberg, Germany: Macintosh et al. 2014, 384).

This activity pattern matches the strontium isotope data from individuals at these sites, with the exception of Stuttgart-Mühlhausen, which sees similar strontium isotope ranges between men and women (Fig. 7). Bulk strontium analyses give an indication of lifetime mobility, rather than repeated movements. Given the variability in the lower limb loading, it seems more likely, however, that a diversity of movements is indicated, but it was mostly more varied for females than males. The strontium isotope data is regarded as evidence for patrilocality (including by the author, e.g. Bickle et al. 2011; Bentley et al. 2012), but here this is suggested as one of a myriad of possible lifeways. It may, however, have been one of the most likely. At Karsdorf (Saxony-Anhalt, Germany), mtDNA haplotypes suggested only limited continuity in maternal lineages across the site's three-century occupation and are thus interpreted as arising from patrilocal practices (Brandt et al. 2014, 100). In sum, the data discussed here strongly suggest some distinct sex-based activities, but also variability, with a greater range of possible mobility for females than for males.

In contrast, the dietary isotopes of carbon and nitrogen suggest greater homogeneity between the sexes in diet and range of food stuffs consumed, though this is variable and not consistent across all LBK sites (Hedges et al. 2013, 355). At the sites where differences do occur, males consistently have high average $\delta^{15} \mathrm{~N}$ values, suggesting greater consumption of meat (Hedges et al. 2013, 355; Zvelebil \& Pettitt 2008). Other dietary differences may be represented by caries rates, which are higher for females than for males (Hedges et al. 2013, 371). Although genetic differences are thought to account for an increased caries risk for women (Ferraro \& Vieira 2010), toothache and loss would have impacted more frequently on female than male lifeways. In turn, this may have then led to particular dietary choices among those women. Overall, however, the variability in dietary-based evidence is less than for the data discussed above, and at the sites where average $\delta^{15} \mathrm{~N}$ values varied between the sexes, the variation was over the same range (Hedges et al. 2013, table 9.6). These data will not encompass all of the possible variations for LBK lifeways (more could be said about ageing here: Bickle \& Fibiger 2014; Hofmann 2009), but it does suggest that, unlike for daily tasks and activities, diet was more a communal sphere rather than a place for social differentiation. Across these different categories, we see places of more and less variation, in which the differences within sexes can be greater than between them, as well as instances of shared practice.

\section{LBK kinship and gender hierarchy}

I now turn to consider whether the image of how difference may have framed the experience of male- and female-sexed bodies and their participation in different tasks impacts on broader models of LBK social organization. For the most part, the LBK is regarded as a non-centralized network formed of kin groups, with the degree of hierarchy debated. Several cases have been made for inherited status, particularly towards the end of the LBK, in which 'rich' female and child graves are attributed to the status of their male relatives (e.g. Jeunesse 1997). For others, social differentiation between households, rather than sex/gender, takes precedence, with larger houses having more economic assets and thus being capable of exerting more influence (e.g. van de Velde 1990). In contrast, houses and households have been regarded as evidence for an egalitarian social structure (Gomart et al. 2015; Hachem 2018). At the site of Cuiry-lès-Chaudardes (Paris basin, France), households were largely self-sufficient but also participated in reciprocity, with incoming groups, for example, using pottery produced in other households as they became established in the village (Gomart et al. 2015, 245). Short houses at the site are associated with wild boar in their pit fills, longer houses with domestic cattle and caprines (Hachem 2018). Rather than interpreting this difference as short houses lacking the resources or capital to access cattle, Hachem (2018) proposes these structures as the home to young couples as they became established in the village and thus argues against strong hierarchical differentiation. What separates this model of egalitarian diversity from those of hierarchy is how difference in used in the analysis of the data. In hierarchical models, difference as defined-by-lack, what someone has will mean someone else does not have it. As men 'have' polished stone tools, woman do not 'have' them, and thus lack them. As some houses 'have' length, other houses do not 'have' it, and thus are short, so the salient character of shortness is not 'having' length. In the models of Gomart et al. (2015) and Hachem (2018), difference is defined-within-itself, and as 


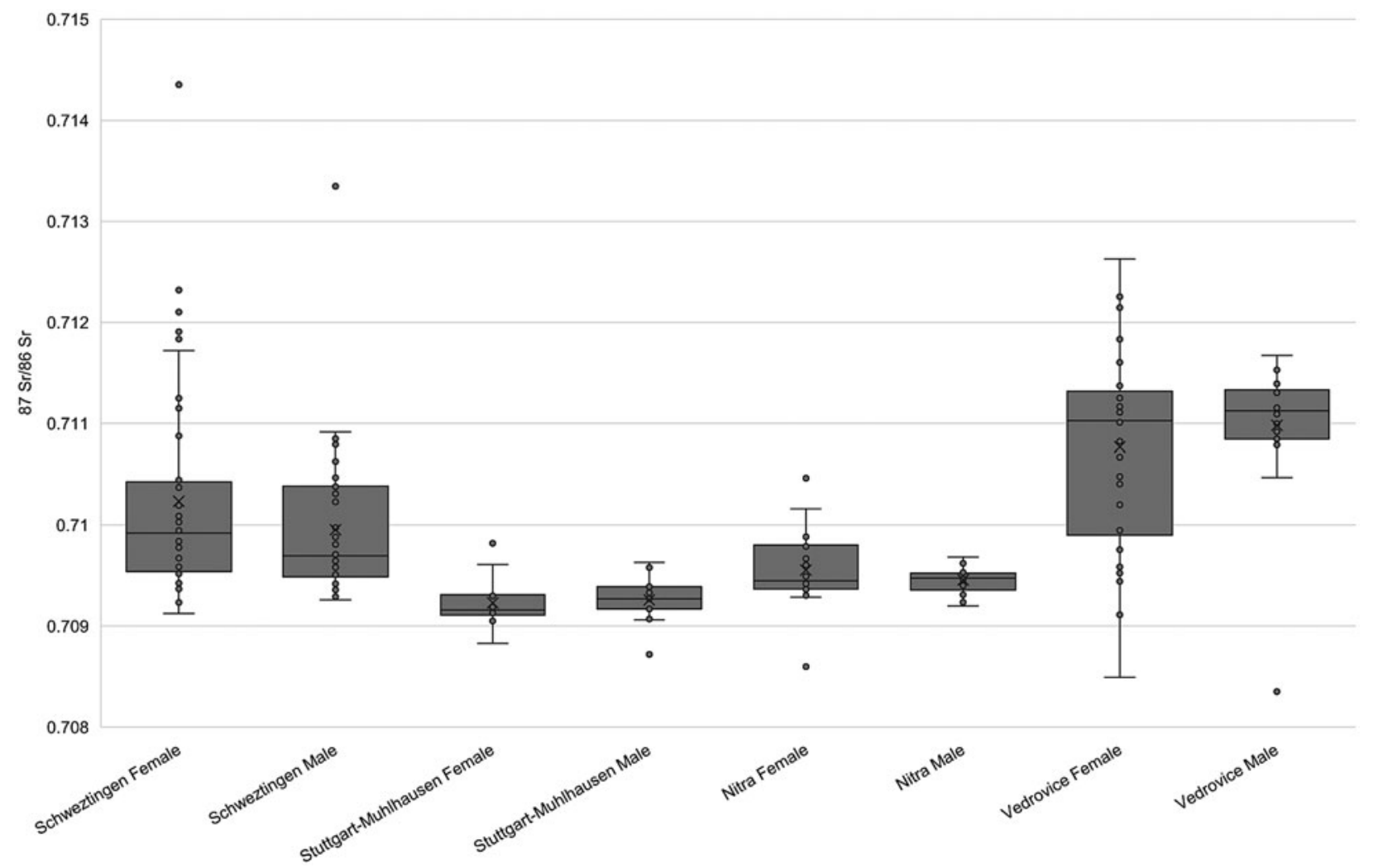

Figure 7. Box and whisker plots of the Strontium isotope ratios for males and females from Nitra (Slovakia), Vedrovice (Czech Republic), Schwetzingen and Stuttgart-Mühlhausen (Baden-Württemberg, Germany). (Based on data from Bickle $\mathcal{E}$ Whittle 2013, Price et al. 2003 and Richards et al. 2008.)

their analysis demonstrates, this leads to making other interpretations possible.

Funerary evidence does not provide a faithful replica of identity or gender as experienced in life and may present certain idealized or manipulated images, yet these 'images' will also act to structure participation in life, and cannot be seen in isolation from other areas of expression (Brück 2004; Nilsson Stutz 2003; Stratton 2016). While 'male' and 'female' do not appear as strong ideals in the burial evidence, there is plenty of evidence that biological sex led to people participating in society in different ways in the LBK. Repeated daily tasks resulted in biological differences in the body, leading to the building of particular strengths, or aches and pains, and perhaps rooted in particular physical or reproductive capacities, and were significant enough to leave a trace in the archaeological evidence. Such differences between the sexes could have been acknowledged, though whether they were used to define or enforce strict categories of identity upon people is debatable. What does tie the burial evidence, osteological and isotopic data together is the degree of variability.
The possibilities for males were more restricted, producing tighter clustering of the data, and less variability, in comparison to females. This may or may not have been understood and elaborated in ways that we would understand as gender, but the evidence presented here counsels against regarding 'male' and 'female' as unequal mirrors of each other, or as a constraining structuring force in the LBK. If binary gender naturalizes hierarchical power asymmetries between men and women (Van Vleet 2008, 7), then I would argue that for the LBK, participation in performing and maintaining descent naturalized and hence limited elaboration of the male sex into particular identities, while providing a greater range of possibilities for the female sex.

Does rejection of a hierarchical binary gender system mean rejecting wholesale a patrilineal descent system? Not necessarily. Diemberger $(1993,91)$ illustrates how among the Khumbo (Nepal), an agricultural society with mostly patrilineal descent, male and female sexes are conceived of as bone and flesh respectively, brought together in the human body. For the Khumbo there are 'no distinct female 
and male worlds' as they operate together, with the division of labour understood as social roles, such as mother or father, rather than as result of the capacity of sex (Diemberger 1993, 100). In a very real way for the Khumbo, flesh and bone are productive forces in the world, brought into action by coming together, and both required in ensuring descent (Diemberger 1993). Among the Sullk'ata (Bolivia), again in a patrilocal and patrilineal society, violence erupts as a means of control because the power hierarchies between men and women, but also between the in-laws of both sexes, are ambiguous (Van Vleet 2008, 177). Van Vleet $(2008,181)$ argues this is because kinship is in constant and fluid negotiation despite broad patrilineal descent patterns. These examples are raised here not to explain the patterns seen in the LBK data, but rather to show that patrilineal descent can arise across varied conceptions of sex, gender and embodiment. In the case of the Khumbo, patrilineal descent does not arise out of a gender hierarchy (Diemberger 1993), while for the Sullk'ata, gender's inherent ambiguity leaves hierarchies open to negotiation and challenge (Van Vleet 2008).

Neither of these examples will exactly match the LBK, arising as they do from the particular historical circumstances of each case. However, they do show that patrilocality covers a range of different understandings of bodies, identities and power systems. As envisioned for the LBK to date, patrilocality has mostly operated in archaeological narratives to place male actors as the central driving force for the society, controlling resources and amassing prestige through material culture, architecture, or social ties, targeted at maintaining descent through the male line (e.g. Moddermann 1988; van der Velde 1979a, b; 1990). In other words, it has naturalized binary gender hierarchies, in which power and status, achieved through amassing critical resources, are ultimately to be found in male control of biological reproduction. This distinct understanding of patrilocality is challenged here, and in contrast, it is argued that LBK social life facilitated variability in experiences and lifeways that cannot be so neatly encapsulated into one model of gender of descent patterns. Certainly, there are instances of shared practice along gender lines. For example, grinding cereals, mainly performed by female-sexed bodies, was a unifying experience in which possibly nearly all women participated (Macintosh et al. 2017; Sládek et al. 2016). However, querns, often treated as a mainly functional object by archaeologists, did not operate to display femaleness in graves as adzes did for men. With many showing evidence for recycling and reuse (Hamon 2008), perhaps querns were passed on, bringing with them a sense of belonging, cooperation and distribution of food not appropriate to the funerary sphere. However, this instance seems to be against a much wider field of variation in tasks and lifeways for women in which there were greater extremes of differentiation than for men. Female mobility may have been one such area, in which freedom to experience and display diverse, multiple or even ambiguous identities may have been signalled in ceramic decoration and production (the 'secondary' motifs). Analysis of the pot-forming techniques by Gomart (2014) found both a mix of major traditions passed on and numerous rarer methods which seem to have reflected the choices of individual potters, as well as instances of flexibility in clay and temper use, rather than pottery being made with strictly monitored or rule-bound methods (cf. Sommer 2001). In rural China, where patrilocal exogamy is widely practised, Judd (2009) has shown that, rather than reducing women to passive exchange objects, such mobility afforded them the freedom to be the active creators of kinship, providing their families with greater flexibility in times of need. Rather than being reduced to symbolic representations of political allegiances made for convenience or for self-aggrandisement, such kinship affiliations are dynamic and sustaining (Judd 2010), diverse and ever opening up-they are constantly becoming, in Deleuzian terms. Such freedoms may have permeated LBK social life, but also tempered by ambiguous social relations. For example, female and juvenile skeletons in the LBK display more evidence for having suffered from violent traumas than males (Hedges et al. 2013, 371), perhaps hinting that women and children could occupy such ambiguous social spaces and identities, permeated with less control naturalized through social norms.

LBK social networks were not static. In the Rhineland, towards the last century of the LBK, longdistance exchange networks as well as regional intersettlement ties are reconfigured, with previously closely associated settlements now seeming to break ties (Claßen 2009; Frirdich 1994). Claßen $(2009,106)$ found that settlements that had previously shared secondary motifs now have none in common. This occurs at the same time that several mass graves representing single violent episodes appear, such as Talheim and Schöneck-Kilianstädten (Germany: Meyer et al. 2015). While both internal political change (Claßen 2009) and external factors such as climate change (e.g. Gronenborn et al. 2014) have been cited as the cause, these sites are thought to represent the decline of the LBK, sometimes envisaged as a crisis 
(Farruggia 2002). However, others have shown that despite its speed, such transformations to the regionally more distinct Middle Neolithic culture that followed the LBK may find their origins with earlier tendencies to regionality from $5300 \mathrm{cal}$. BC, with different trajectories in different regions (Hofmann 2015; Link 2015). Pottery was intimately involved in materially signalling these changes, perhaps an active part of innovation and forming new identities (Hofmann 2015, 468). In Saxony (Germany) and Bohemia, a more gradual transition from the LBK to the succeeding Stichbandkeramik (SBK) culture has been suggested, based in part on the co-occurrence of LBK linear designs and the alternating double strokes of the SBK ceramic styles in the same features and interpreted as a continuation of LBK-specific styles of innovation in pot design (Vondrovský et al. 2016). Perhaps the assemblage of mobility, pottery, women and ambiguity meant that ceramic styles and techniques were spheres that could readily adapt and flow into new points of view on selfidentification, and were ready to open up to negotiating differences-within-itself.

\section{Conclusion}

In the LBK, gender is certainly not consistently expressed across all forms of evidence, as noted for Neolithic gender more widely by Robb and Harris (2017). While biological sex may not have defined gender during the LBK, it is argued here that sexed bodies did matter. This pattern is played out across the spheres examined here: funerary, diet, mobility and daily tasks. In the funerary sphere, burials were not subject to defined and policed social norms, nor were they places of endless variation, but rather more creative elaboration of the familiar things, bodies and exchanges that tied social, possibly kin, groups together (Frirdich 2003). Thus the differences seen across the grave good assemblages and treatments suggest that people were more free to be creative with the creation of female-sexed individuals' graves than for male. While everyday activities and tasks may have divided by biological sex, this did not prevent diverse lifeways from developing, again with female bodies showing greater diversity than males. We cannot be certain that the body was the only or chief source of identity (e.g. Moore 1994a; Strathern 1988), but we can argue that sexed bodies opened up particular ways of participating in the LBK society, rather than providing a pervasive and all-encompassing hegemony for gendered ideology. While I favour descent as a specific form of 'connection' that was of concern in the formation of LBK identities, others may yet come to the fore.

The purpose of this paper has been to consider how difference and variation, rather than focusing on identifying major patterns or norms, might change the ways we interpret sex and gender in Neolithic contexts. In order to do so, it has been necessary to consider how differences were being theorized in the LBK context and in archaeology more generally. It is through attempting to throw off difference as excluding, as defined-by-lack, and moving towards difference defined-within-itself, that I propose Deleuzian thought has exploratory power for archaeology. Following Stark (2016, 80), Deleuze's (\{1994\} 2009) Difference and Repetition is where his philosophical position emerges as a deliberate attempt to unpick the prevailing conceptions of identity as developed in psychoanalytical or Freudian thought. Rejecting identity as cast by this approach becomes one of the political aims of his later works. As archaeologists we have been reluctant to engage with the legacy of psychoanalysis (with some exceptions, e.g. Thomas 2004, 161-9), and while it may not be a productive route for analysing past societies, we have not been vigilant of the ways it shapes approaches to interpreting differences in archaeological data. Attending to difference (here inspired by the Deleuzian approach) has permitted a new consideration of sex, identity and kinship in the LBK to emerge, with consequences for how social change across the Neolithic is envisaged. Above all, narratives of prehistory need to be alert to where binary genders are uncritically used to form the foundation for social forms-on which larger models of social change are then built.

\section{Acknowledgements}

Many of the data discussed here are drawn from the $L B K$ Lifeways project (2008-12), and I express my profound thanks to the project's collaborators, particularly R. Alex Bentley, Linda Fibiger, Julie Hamilton, Robert Hedges, Daniela Hofmann and Alasdair Whittle (for a full list of collaborators and data, see Bickle \& Whittle 2013). This project was funded by the Arts and Humanities Research Council, UK (AH/F018126/1). The paper was prepared through funding for the project Counter Culture: Investigating Neolithic Social Diversity, funded by the Arts and Humanities Research Council, UK (AH/R002622/1). Many thanks to Colleen Morgan, Oliver Harris, Daniela Hofmann, Alasdair Whittle and Stephanie Wynne-Jones, who read and commented on draft versions of this text. I also owe a debt of gratitude to the two anonymous reviewers for their encouraging comments, which improved the text. 


\section{Penny Bickle \\ University of York \\ King's Manor \\ York YO1 7EP \\ $U K$ \\ Email: penny.bickle@york.ac.uk}

\section{References}

Baxter, M.J., 1994. Exploratory Multivariate Analysis in Archaeology. Edinburgh: Edinburgh University Press.

Bentley, R.A., P. Bickle, L. Fibiger, et al., 2012. Community differentiation and kinship among Europe's first farmers. Proceedings of the National Academy of Sciences of the United States of America 109(24), 9326-30.

Bickle, P. \& L. Fibiger, 2014. Ageing, childhood and social identity in the early Neolithic of central Europe. European Journal of Archaeology 17(2), 208-28.

Bickle, P., D. Hofmann, R.A. Bentley, et al., 2011. Roots of diversity in a Linearbandkeramik community: isotope evidence at Aiterhofen (Bavaria, Germany). Antiquity 85, 1243-58.

Bickle, P. \& A. Whittle (eds), 2013. The First Farmers of Central Europe: Diversity in LBK lifeways. Oxford: Oxbow.

Boës, E., 2000. Evolution des comportements funéraires entre les VIe et Ve millénaires avant J.-C. en Alsace [Evolution of funerary practices between the 6th and 5th millennia BC in Alsace]. Cahiers Alsaciens d'Archéologie d'Art et d'Histoire 43, 5-18.

Braidotti, R., 2011. Nomadic Subjects: Embodiment and sexual difference in contemporary feminist theory (2nd edn). New York (NY): Columbia University Press.

Braidotti, R., 2013. The Posthuman. Cambridge: Polity Press.

Brandt, G., W. Haak, C.J. Adler, et al., 2013. Ancient DNA reveals key stages in the formation of central European mitochondrial genetic diversity. Science 342(6155), 257-61.

Brandt, G., C. Knipper, N. Nicklish, R. Ganslmeier, M. Klamm \& K.W. Alt, 2014. Settlement burials at the Karsdorf LBK site, Saxony-Anhalt, Germany: biological ties and residential mobility, in Early Farmers: The view from archaeology and science, eds A. Whittle \& P. Bickle. Oxford: Oxford University Press for the British Academy, 95-114.

Brück, J., 2004. Material metaphors: the relational construction of identity in early Bronze Age burials in Ireland and Britain. Journal of Social Archaeology 4(3), 307-33.

Busby, C., 1999. Agency, power and personhood: discourses of gender and violence in a fishing community in south India. Critique of Anthropology 19(3), 227-48.

Butler, J., 1990. Gender Trouble: Feminism and the subversion of identity. London: Routledge.

Butler, J., 1993. Bodies That Matter: On the discursive limits of 'sex'. London: Routledge.
Chamberlain, A.T., 2006. Demography in Archaeology. Cambridge: Cambridge University Press.

Claßen, E., 2009. Settlement history, land use and social networks of early Neolithic communities in western Germany, in Creating Communities: New advances in central European Neolithic research, eds D. Hofmann \& P. Bickle. Oxford: Oxbow, 95-110.

Crellin, R., 2017. Changing assemblages: tracing vibrant matter in burial assemblages. Cambridge Archaeological Journal 27(1), 111-25.

Delanda, M., 2006. A New Philosophy of Society: Assemblage theory and social complexity. London: Continuum.

Deleuze, G., [1994] 2009. Difference and Repetition. London: Continuum.

Deleuze, G. \& F. Guattari, [1983] 2013a. Anti-Oedipus: Capitalism and schizophrenia. London: Bloomsbury Academic.

Deleuze, G. \& F. Guattari, [1987] 2013b. A Thousand Plateaus. London: Bloomsbury Academic.

Diemberger, H., 1993. Blood, sperm, soul and the mountain: gender relations, kinship and cosmovision among the Khumbo (N.E. Nepal), in Gendered Anthropology, ed. T. del Valle. London/New York: Routledge, 88-127.

Dohrn-Ihmig, M., 1983. Das bandkeramische Gräberfeld von Aldenhoven-Niedermerz, Kreis Düren [The Bandkeramik cemetery of Aldenhoven-Niedermerz, Kreis Düren]. Rheinische Ausgrabungen 24, 47-190. Cologne: Rheinland-Verlag.

Eisenhauer, U., 2003. Matrilokalität in der Bandkeramik? Ein ethnologisches Modell und seine Implikationen [Matrilocality in the Bandkeramik? An ethnological model and its implications]. Archäologische Informationen 26, 321-31.

Farruggia, J.-P., 2002. Une crise majeure de la civilisation du Néolithique danubien des années 5100 avant notre ère [A major crisis in the Neolithic Danubian culture after 5100 cal BC]. Archeologické rozhledy 54, 44-98.

Ferraro, M. \& A.R. Vieira, 2010. Explaining gender differences in caries: a multifactorial approach to a multifactorial disease. International Journal of Dentistry 2010. DOI: $10.1155 / 2010 / 649643$

Fowler, C., 2013. The Emergent Past: A relational realist archaeology of early Bronze Age mortuary practices. Oxford: Oxford University Press.

Frirdich, C., 1994. Kulturgeschichtliche Betrachtungen zur bandkeramik im Merzbachtal [Culture-historical reflections on the Bankeramik in the Merzbachtal], in Die Bandkeramik im Merzbachtal auf der Aldenhovener Platte [The Bandkermaik of the Merzbachtal, Aldenhovener Plateau], eds J. Lüning \& P. Stehli. Bonn: Habelt, 207-393.

Frirdich, C., 2003. Strukturen im Wandel: Ein bandkeramisches Gräberfeld entsteht [Structures in transition: The creation of a Bandkeramik cemetery], in Archäologische Perspektiven: Analysen und Interpretationen im Wandel. Festschrift für Jens Lüning zum 65. 
Geburtstag [Archaeological perspectives: Analysis and interpretation in transition. Festschrift for Jens Lüning on his 65th birthday], eds J. Eckert, U. Eisenhauer \& A. Zimmermann. Rahden: Marie Leidorf, 545-9.

Geller, P.L., 2008. Conceiving sex: fomenting a feminist bioarchaeology. Journal of Social Archaeology 8(1), 113-38.

Gomart, L., 2014. Traditions, techniques et production céramique au Néolithique ancient: Étude de huit sites rubanés du nord est de la France et de Belgique [Traditions, techniques and production of early Neolithic ceramics: Study of eight Bandkeramik sites from the northeast of France and Belgium]. Leiden: Sidestone.

Gomart, L., L. Hachem, C. Hamon, F. Giligny \& M. Ilett, 2015. Household integration in Neolithic villages: a new model of the Linear Pottery Culture in westcentral Europe. Journal of Anthropological Archaeology $40,230-49$.

Grauer, A.L. (ed.), 2012. A Companion to Palaeopathology. Chichester: Wiley-Blackwell.

Gronenborn, D., 1999. Variations on a basic theme: the transition to farming in southern central Europe. Journal of World Prehistory 13(2), 123-210.

Gronenborn, D., H.-C. Strien, A. Dietrich \& F. Sirocko, 2014. 'Adaptive cycles' and climate fluctuations: a case study from Linear Pottery Culture in western central Europe. Journal of Archaeological Science 51 (2014), 73-83.

Grosz, E., 1994. Volatile Bodies: Towards a corporeal feminism. Indianapolis (IN): Indiana University Press.

Grosz, E., 2011. Becoming Undone: Darwinian reflections on life, politics, and art. Durham/London: Duke University Press.

Haack, F., 2008. Gewandknebel, Geweihknebel, Knochenknebel, Spondylusknebel - Zur Technologie, Typologie und Chronologie linienbandkeramischer Grabbeigaben [Garment-toggles, antler pendants, bone pendants and Spondylus pendants - on the technology, typologie and chronology of Linearbandkeramik grave goods], in Kumpf, Kalotte, Pfeilschaftglätter: zwei Leben für die Archäologie. Gedenkschrift für Annemarie Häusser und Helmut Spatz [Bowls, skull caps, arrowshafts: two lives for archaeology. Commemorative publication for Annemarie Häusser and Helmut Spatz], eds F. Falkenstein, S. Schade-Lindig \& A. Zeeb-Lanz. Rahden: Marie Leidorf, 117-28.

Hachem, L., 2000. New observations on the Bandkeramik house and social organization. Antiquity 74, 308-12.

Hachem, L., 2018. Animals in LBK society: identity and gender markers. Journal of Archaeological Science: Reports 20(A1-A2), 910-21.

Hamon, C., 2008. Functional analysis of stone grinding and polishing tools from the earliest Neolithic of northwestern Europe. Journal of Archaeological Science 356 (6), 1502-20.
Harris, O.J.T., 2017. Assemblages and scale in archaeology. Cambridge Archaeological Journal 27(1), 127-39.

Harris, O.J.T., 2018. More than representation: multiscalar assemblages and the Deleuzian challenge to archaeology. History of the Human Sciences 31(3), 83-104.

Harris, O.J.T. \& C. Cipolla, 2017. Archaeological Theory in the New Millennium: Introducing current perspectives. London: Routledge.

Häusler, A., 1994. Grab- und Bestattungssitten des Neolithikums und der frühen Bronzezeit in Mitteleuropa [Grave and burial customs of the Neolithic and early Bronze Age in central Europe]. Zeitschrift für Archäologie 28(1), 23-61.

Hedges, R., R.A. Bentley, P. Bickle, et al., 2013. The supra-regional approach, in The First Farmers of Central Europe: Diversity in LBK lifeways, eds P. Bickle \& A. Whittle. Oxford: Oxbow, 343-84.

Hofmann, D., 2009. Cemetery and settlement burial in the Lower Bavarian LBK, in Creating communities: New advances in central European Neolithic research, eds D. Hofmann \& P. Bickle. Oxford: Oxbow, 220-34.

Hofmann, D., 2013. Intimate connection: bodies and substances in flux in the early Neolithic of central Europe, in Relational Archaeologies: Humans, animals, things, ed. C. Watts. London/New York: Routledge, 154-72.

Hofmann, D., 2015. What have genetics ever done for us? The implications of aDNA data for interpreting identity in early Neolithic central Europe. European Journal of Archaeology 18(3), 454-76.

Hofmann, D. \& A. Whittle, 2008. Neolithic bodies, in Prehistoric Europe: Theory and practice, ed. A. Jones. Oxford: Blackwell, 287-311.

Jeunesse, C., 1997. Pratiques funéraires au Néolithique ancien: sépultures et nécropoles danubiennes 5500-4900 av. J.-C [Early Neolithic funerary practices: graves and cemeteries of the Danubian culture, 5500-4900 cal BC]. Paris: Errance.

Jones, A., 2005. Lives in fragments? Personhood and the European Neolithic. Journal of Social Archaeology 5 (2), 193-224.

Joyce, R., 2000. Gender and Power in Prehispanic Mesoamerica. Austin (TX): University of Texas Press.

Joyce, R., 2008. Ancient Bodies, Ancient Lives: Sex, gender and archaeology. London: Thames \& Hudson.

Judd, E.R., 2009. 'Families we create': women's kinship in rural China as spatialized practice, in Chinese Kinship: Contemporary anthropological perspectives, eds S. Brandtstädter \& G.D. Santos. Oxford/New York: Routledge, 29-47.

Judd, E.R., 2010. Family strategies: fluidities of gender, community and mobility in rural West China. The China Quarterly 204, 921-34.

Judd, M.A. \& C.A. Roberts, 1999. Fracture trauma in a medieval British farming village. American Journal of Physical Anthropology 109(2), 229-43.

Krahn, C., 2003. Überlegungen zum Interaktionssytem der bandkeramischen Siedlungen auf der Aldenhovener 
Platte [Reflections on the networks of Bandkeramik settlements on the Aldenhoven Plateau], in Archäologische Perspektiven: Analysen und Interpretationen im Wandel. Festschrift für Jens Lüning zum 65. Geburtstag [Archaeological perspectives: Analysis and interpretation in transition. Festschrift for Jens Lüning on his 65th birthday], eds J. Eckert, U. Eisenhauer \& A. Zimmermann. Rahden: Marie Leidorf, 515-44.

Lanchon, Y., F. Bostyn \& L. Hachem, 1997. L'étude d'un niveau archéologique néolithique et ses apports à la compréhension d'un site d'habitat: l'exemple de Jablines 'La Pente de Croupeton' (Seine-et-Marne) [Study of a Neolithic floor and its contribution to the understanding of a settlement site: The example of Jablines 'La Pente de Croupeton' (Seine-et-Marne)], in Espaces physiques, espaces sociaux dans l'analyse interne des sites du Néolithique à l'Âge du Fer [Physical spaces, social spaces in the analysis of internal layouts of sites from the Neolithic to the Iron Age], ed. A. Bocquet. Amiens: Centre des Travaux Historiques et Scientifiques, 327-44.

Last, J., 1998. The residue of yesterday's existence: settlement space and discard at Miskovice and Bylany, in Bylany: Varia 1, ed. I. Pavlů. Prague: Archeologický ústav AV ČR, 17-45.

Link, T., 2015. New ideas in old villages. Interpreting the genesis of the Stroked Pottery Culture. Anthropologie 53(3), 251-362.

Macintosh, A.A., R. Pinhasi \& J.T. Stock, 2014. Lower limb skeletal biomechanics track long-term decline in mobility across $\sim 6150$ years of agriculture in central Europe. Journal of Archaeological Science 52(2014), 376-90.

Macintosh, A.A., R. Pinhasi \& J.T. Stock, 2017. Prehistoric women's manual labor exceeded that of athletes through the first 5500 years of farming in central Europe. Science Advances 3(11), eaao3893.

Meyer, C., C. Lohr, D. Gronenborn \& K.W. Alt, 2015. The massacre mass grave of Schöneck-Kilianstädten reveals new insights into collective violence in Early Neolithic Central Europe. Proceedings of the National Academy of Sciences of the United States of America 112(36), 11217-22.

Meskell, L., 1996. The somatization of archaeology: institutions, discourses, corporeality. Norwegian Archaeological Review 29(1), 1-16.

Meskell, L. \& R. Joyce, 2003. Embodied Lives: Figuring Ancient Maya and Egyptian experience. London: Routledge.

Milledge Nelson, S. (ed.), 2006. Handbook of Gender in Archaeology. Lanham (MD): Altamira.

Modderman, P.J.R., 1988. The Linear Pottery culture: diversity in uniformity. Berichten van de Rijksdienst voor het Oudheidkundig Bodemonderzoek 38, 63-139.

Moore, H.L., 1993. The differences within and the differences between, in Gendered Anthropology, ed. T. del Valle. London/New York: Routledge, 193-204.
Moore, H.L., 1994a. A Passion for Difference: Essays in anthropology and gender. Cambridge: Polity.

Moore, H.L., 1994b. Understanding sex and gender, in Companion Encyclopedia of Social Anthropology: Humanity, culture, and social life, ed. T. Ingold. London: Routledge, 813-30.

Neugebauer-Maresch, C. \& E. Lenneis, 2015. Das Linearbandkeramische Gräberfeld von Kleinhadersdorf [The Kleinhadersdorf Linearbandkeramik cemetery]. Vienna: Österreichischen Akademie der Wissenschaften.

Nieszery, N., 1995. Linearbandkeramische Gräberfelder in Bayern [Linearbandkeramik cemeteries in Bavaria]. Espelkamp: Marie Leidorf.

Nilsson Stutz, L., 2003., Embodied Rituals and Ritualized Bodies: Tracing ritual practices in late Mesolithic burials. Lund: Wallin \& Dahlholm.

Pavúk, J., 1972. Zum Problem der Gräberfelder mit der Linienbandkeramik [On the problem of cemeteries in the Linearbandkeramik]. Alba Regia 12, 123-30.

Price, T.D., J. Wahl, C. Knipper, E. Burger-Heinrich, G. Kurtz \& R.A. Bentley, 2003. Das bandkeramische Gräberfeld vom „Viesenhäuser Hof" bei StuttgartMühlhausen: Neue Untersuchungsergebnisse zum Migrationsverhalten im frühen Neolithikum [The Bandkeramik cemetery of "Viesenhäuser Hof", Stuttgart-Mühlhausen: new research on the migration behavour of the early Neolithic]. Fundberichte aus Baden-Würtemberg 27, 23-58.

Ramminger, B., 2007. Wirtschaftsarchäologische Untersuchungen $\mathrm{zu}$ alt- und mittelneolithischen Felsgesteingeräten in Mittel- und Nordhessen: Archäologie und Rohmaterialversorgung [Economic archaeological research on the early and middle Neolithic ground stone tools from Middle and Northern Hessen: Archaeology and the search for raw materials]. Rahden: Marie Leidorf.

Richards, M.P., J. Montgomery, O. Nehlich \& V. Grimes, 2008. Isotopic analysis of humans and animals from Vedrovice. Anthropologie 46(2-3), 185-94.

Robb, J. \& O.J.T. Harris, 2013. The Body in History: Europe from the Palaeolithic to the future. Cambridge: Cambridge University Press.

Robb, J. \& O.J.T. Harris, 2017. Becoming gendered in European prehistory: was Neolithic gender fundamentally different? American Antiquity 83(1), 128-47.

Röder, B., 1998. Jungsteinzeit: Frauenzeit? Frauen in frühen bäuerlichen Gesellschaften Mietteleuropas [The Neolithic: The time of women? Women in the early farming societies of central Europe], in Frauen Zeiten - Spuren [Women - Times - Traces], eds B. Auffermann \& G.-C. Weniger. Mettmann: Neanderthal-Museum, 241-69.

Sládek, V., C.B. Ruff, M. Berner, B. Holt, M. Niskanen, E. Schuplerová \& M. Hora, 2016. The impact of subsistence changes on humeral bilateral asymmetry in terminal Pleistocene and Holocene Europe. Journal of Human Evolution 92, 37-49. 
Sofaer Derevenski, J., 1997. Age and gender at the site of Tiszapolgár-Basatanya, Hungary. Antiquity 71, 875-89.

Sommer, U., 2001. 'Hear the instructions of thy father, and forsake not the law of thy mother': change and persistence in the European Early Neolithic. Journal of Social Archaeology 1(2), 244-70.

Stark, H., 2016. Feminist Theory After Deleuze. London: Bloomsbury Academic.

Strathern, M., 1988. The Gender of the Gift. Berkeley (CA): University of California Press.

Stratton, S., 2016. 'Seek and you shall find'. How the analysis of gendered patterns in archaeology can create false binaries: a case study from Durankulak. Journal of Archaeological Method and Theory 23(3), 854-69.

Strien, H.-C., 2000. Untersuchungen zur Bandkeramik in Württemberg [Studies on the Bandkeramik in Württemberg]. Bonn: Habelt.

Strien, H.-C., 2010. Mobilität in bandkeramischer Zeit im Spiegel der Fernimporte [Mobility in the Bandkeramik period through the lens of longdistance imports], in Die Neolithisierung Mitteleuropas/The spread of the Neolithic to central Europe, eds D. Gronenborn \& J. Petrasch. Mainz: Römisch-Germanisches Zentralmuseum, 497-508.

Thévenet, C., 2009. Les sépultures rubanées du Bassin parisien: composition de l'échantillon funéraire et implantation sépulchrale [The Bandkeramik burials of the Paris Basin: funerary practices and grave styles], in Krisen - Kulturwandel - Kontinuitäten: Zum Ende der Bandkeramik in Mitteleuropa [Crisis Culture change - Continuity: The end of the Bandkeramik in central Europe] ed. A. Zeeb-Lanz. Rahden: Marie Leidorf, 111-27.

Thomas, J., 2004. Archaeology and Modernity. London: Routledge.

van de Velde, P., 1979a. On Bandkeramik social structure. Analecta Praehistorica Leidensia 12, 1-242.

van de Velde, P., 1979b. The social anthropology of a Neolithic cemetery in the Netherlands. Current Anthropology 20(1), 37-58.

van de Velde, P., 1990. Bandkeramik social inequality - a case study. Germania 68(1), 19-38.

Van Vleet, K.E., 2008. Performing Kinship: Narrative, gender, and the intimacies of power in the Andes. Austin (TX): University of Texas Press.

Veit, U., 1993. Burials within settlements of the Linienbandkeramik and Stichbandkeramik cultures of central Europe: on the social construction of death in Early-Neolithic society. Journal of European Archaeology 1(1), 107-40.
Veit, U., 1996. Studien zum Problem der Siedlungsbestattung im europäischen Neolithikum [Studies on the problems of Settlement burials in the European Neolithic]. Münster: Waxmann.

Villotte, S. \& C.J. Knüsel, 2013. 'I sing of arms and of a man. .': medial epicondylosis and the sexual division of labour in prehistoric Europe. Journal of Archaeological Science 43(2013), 168-74.

Vondrovský, V., J. Beněs, M. Divišová, L. Kovačiková \& P. Šida, 2016. From LBK to SBK: pottery, bones, lithics and houses at the Neolithic site of Hrdlovka, Czech Republic. Open Archaeology 2(1), 303-27.

Weiss, K., 1972. On the systematic bias in skeletal sexing. American Journal of Physical Anthropology 37(2), 239-50.

Whittle, A., 2012. Being alive and being dead: house and grave in the LBK, in Image, Memory and Monumentality: Archaeological engagements with the material world (a celebration of the academic achievements of Professor Richard Bradley), eds A.M. Jones, J. Pollard, M.J. Allen \& J. Gardiner. Oxford: Oxbow, 194-206.

Whittle, A. \& P. Bickle, 2013. Performing LBK lifeways, in The First Farmers of Central Europe: Diversity in LBK lifeways, eds P. Bickle \& A. Whittle. Oxford: Oxbow, 385-401.

Wolfram, S., 2013. Two sides of the coin: ceramic taphonomy and domestic space in the Linear Pottery settlements Hanau-Klein-Auheim and Eythra (Germany), in The Domestic Space in LBK Settlements, eds C. Hamon, P. Allard \& M. Ilett. Rahden: Marie Leidorf, 79-89.

Zvelebil, M. \& P. Pettitt, 2008. Human condition, life, and death at an early Neolithic settlement: bioarchaeological analyses of the Vedrovice cemetery and their biosocial implications for the spread of agriculture in central Europe. Anthropologie 46(2-3), 195-218.

\section{Author biography}

Penny Bickle is a Senior Lecturer in Archaeology at the University of York. The main focus of her research is the Neolithic period, with a particular interest in how bioarchaeological methods can be applied to archaeological remains to inform on issues of identity and social diversity. Much of her work has focused on the Linearbandkeramik (LBK) and central Europe. Her PhD was awarded by the University of Cardiff in 2009, on the theme of longhouses and Neolithic architecture. 